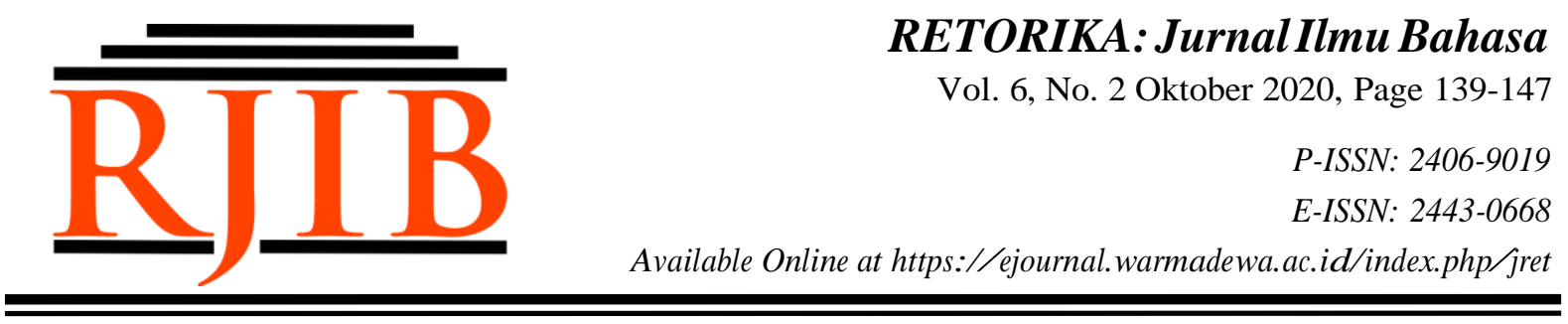

\title{
Values of Life in The Wild Duck by Hendrik Ibsen
}

\author{
Gusti Ayu Made Rai Suarniti \\ Universitas Warmadewa, Denpasar-Bali, Indonesia \\ raisuarniti78@gmail.com

\begin{tabular}{|l|l|}
\hline Received: 04/08/2020 & Revised: $21 / 10 / 2020$ \\
\hline How to cite (in APA style): \\
Suarniti, G, A, M, R. (2020). Values of Life in The Wild Duck by Hendrik Ibsen. Retorika: Jurnal Ilmu Bahasa, 6(2), 139- \\
147. doi: https://doi.org/10.22225/jr.6.2.1972.139-147
\end{tabular}

Abstract - This study aims to analyze and discuss the values in Hendrik Ibsen's The Wild Duck. The method used in this study is descriptive. The data are a drama entitled The Wild Duck (1959). A library research method is applied in collecting the data. Furthermore, the data is analyzed qualitatively. Based on the result of the analysis, it was revealed that there are five kinds of Values found in The Wild Duck which are Moral Value, Social Value, Personal Value, Spiritual Value and Family Value. The most presented type is a moral value, it is about honesty. Social value is about interaction with around, friendship, respect to each other, justice. A personal value is a personality. Spiritual is non-material, it means the values of truth, inner peace, righteousness, and non-violence and the last is family values are beliefs, function as a family, ideals.

Keywords: The Wild Duck, Values, Life

\section{INTRODUCTION}

Literature is a author's reflection on life and livings. This is combined with the power of imagination and creativity supported by experience and observation. According to Klarer (2004:1) in most cases, literary works are referred to as whole written expressions, with the limitation that not all written documents can be categorized as literary works in a more precise sense. Furthermore, according to Goodman (1996:vii), a literature includes written forms that deliberately and creatively experiment with language to suggest images and ideas that engage the reader's imagination. Literature can then be said to be a creative written work by an author with aesthetic values that make literature considered an art.

Literature is a form of art. Literature can be a significant someone experiences and expression of someone nature. Literature is a creative art because we can express our ideas, feelings, and expressions. According to Wellek \& Warren (1962) through its expressive side, literature conveys the attitude and tone of the author. He also wants to influence and persuade readers' attitudes and ultimately change readers. Literature also has an aesthetic value which refers to the characteristics of literature such as style, composition, and prepositional style in general (1962:23). Literature can be divided into fiction and non-fiction. Fiction is the story based on the unreality. Fiction consists of prose, poetry and drama. The drama is often called play, shows values. However, the values of the drama, for instance, Hendrik Ibsen's The Wild Duck is chosen to be analyzed because it has many values and it is very interesting to be discussed.

Some latest related studies carried out about The Wild Duck. Mathias (2016) conducted research about Symbolic Analysis of Character in Ibsen's The Wild Duck. The results of this study showed that the thing that fills [Ibsen's] 
mind is the male individual, and he measures the value of the community according to how it helps or hinders a person from being himself. $\mathrm{He}$ has the ideal standard which he places upon society and it is from this measure that his social criticism continues. Kusumawati (2017) also conducted a similar study which discusses the motives and manifestations of the main characters of The Wild Duck (Gregers Werle and Hjalmar Ekdal) have mental disorders that are presented in their behavior and thoughts. Gregers Werle has neurotic characteristics that are promoted in his personality. Her personality motive is excessive father domination which is depressed in her subconscious which makes her independent and persistent. Meanwhile, Hjalmar Ekdal has psychotic characteristics that are supported in his personality. His personality motive is to cover up the father's function which leads to a misleading life, and that makes him a foolish and selfish person.

Another similar study is also carried out by Baroud (2019) which analyze the tension between illusion and reality in H. Ibsen's The Wild Duck. The result revealed that in The Wild Duck, the priest is drunk, the soldier is broken, the idealist is mad, the doctor is ill. They have all sunk metaphorically into the bottom of the sea like the bird the wild duck. But having said that we have got the right to ask and ponder: how should we run our life, according to Gregers' Idealism or to Dr Relling's Realism. Neither, of course, is trustworthy. Of the two manipulators of the plot, the one is fanatic, neurotic, sadistic, and perhaps mad; the other is a drunkard and a disgrace to his profession. Life cannot be run according to either to absolute idealistic or realistic principles. Life is a dynamic process whose only reality is built on a kind of compromise or reconciliation between our desires and our own circumstances. Based on the background and the latest related study above, this study aims to discover the values in Hendrik Ibsen's The Wild Duck.

\section{METHOD}

This study applied a descriptive qualitative method in which the data are taken from a drama entitled The Wild Duck (1959) by Hendrik Ibsen. In collecting the data, the library research method is applied. The data collection was conducted by watching and reading the drama several times in order to get a suitable meaning that related to the topic. Furthermore, in analyzing the data, the data are classified and analyzed based on the theory of literature and theory of values. The theories of literature are proposed by Kenney (1966) about the element of fiction and Reaske (1984) about the structure of the plot. Meanwhile, the theories of psychology are proposed by Gulla (2010) about creating values in life, Audi (2007) about moral value, Leicester (2004) about a spiritual value and Wood \& Leighton (2010) about social value.

\section{RESULTS AND DISCUSSION}

Value means general, moral or oriental conceptions of the world or sometimes just attitudes, dispositions, needs, and preferences. This goal is considered valid and binding by society. They define what is important, valuable and worth fighting for. Sometimes, values have been interpreted as "the standard that determines the end of the action". Thus, value is a collective conception of what is considered good, desirable, and appropriate or bad, unwanted and inappropriate in a culture. All of the values in Ibsen's The Wild Duck will be explained clearly as the following.

\section{a. Moral Value}

Ibsen's The Wild Duck offers the morality of love bravery, enthusiasm kindhearted, loyalty, peace-loving, and never giving up all of these moralities will be explained as the followings:

\section{i. Love}

Ibsen's The Wild Duck teaches us a lot of love between the actors, as Hedvig who really loves his father, Hjalmar as Hedvig's father, in the society aroused suspicion Hedvig is not his daughter after Gregers have told him about the truth in the past about the black relationship between Hakon Werle and Gina (Hedvig's mother). Because of that Hjalmar attitude so much change to Hedvig. It makes Hedvig has got heartache but she really loves his father. She decides to kill the wild duck at the attic to show her dedication as a daughter because Hjalmar does not like that wild duck in the attic. Gina is very surprised when she hear a gunshot, sound heard from the attic. She thinks Hjalmar has 
an old father who makes a mistake in using a gun and injured himself. Gina immediately come to Hjalmar and tell him about what happened hears all of the accidents can be seen as the following questions:

(A pistol shot is heard from within the attic)

Gregers (with a happy shout). Hjalmar!

Hjalmar. Listen to that. He must need go shoot too.

Gina (Coming in). Hjalmar, I think grandfather is blundering about in the attic by himself. (Ibsen in Heffner, 1959:425).

\section{ii. Bravery}

Ibsen's The Wild Duck teaches us the value of bravery through the character of Gregers. He is a very brave man to reveal the truth about misfortunate experiences of Ekdal Family to his friend. Here, is Hjalmar does not know about the black relationship between Gina (Hjalmar's wife) with Hakon Werle (Old Werle is Gregers' father). In order to prove the truth he must against his father (Hakon Werle). Gregers is the only Old Werle's son. He really hates his father's relationships toward Gina (his former schoolmate). Gregers leaves the house to meet Hjalmar, He wants to tell him about all the lies that he not realized. Worried about Gregers has opposition, Old Werle comes to the studio to meet Gregers where Hjalmar lives and makes Gina surprised by the arrival of Old Werle. It can be seen as the following:

(A knock is heard at the outer door.)

Hedvig. Somebody is knocking, mother.

Hjalamar. There now, I suppose we are going to be pestered with people! Gina. Let me go and see. (She goes to the door and opens it, starts, shudders and draws back.) Oh, my goodness! (The elder
Werle, wearing a fur coat, steps into the doorway.) (Ibsen in Heffner, 1959: 396).

\section{iii. Enthusiasm}

Ibsen's The Wild Duck teaches us the value of enthusiasm through the character of Hjalmar. This is a special character of Hjalmar with his family's poor circumstances. That makes Hjalmar has a big curiosity to be changed his family's condition to be better in the future. He wants to determine Hedvig has a happy life in future and lives in a moderate style. As well as for his poor father "Old Ekdal. With enthusiasm, Hjalmar convinces his little family. Hjalmar said that he will determine Gina, Hedvig and Old Ekdal's life will always be sufficient from good income in the studio. He believes that everything will be fine. It can be seen as the following:

Hjalmar (lowering his voice). I shall fulfil it, I say. The day will come when-when-.and that is why it is a good thing we got the room let; it puts me in a more independent position. And a man who as a mission in life must be independent of others. (Stands by his father's chair and speaks with emotion.) Poor old white-haired father! You may depend on your Hjalmar! He has broad shouldersstrong shoulders, at any rate. Some fine day you shall wake up, and-. (To Gina.) Don't you believe it? (Ibsen in Heffner, 1959: 382).

\section{iv. Kindhearted}

In this drama, Hjalmar is a schoolfellow with Gregers Werle. Here, Hjalmar does not want to make his friend feels disappointed with him. Through his kindhearted he tries to fulfil Gregers' needs from him. After Gregers talking to his father (Old Werle) who come to meet him in Hjalmar's studio. Gregers asks Hjalmar to go out 
with him. It seems that Gregers wants to say a very important thing to Hjalmar. But at the same time, Gina and Mr Relling advise Hjalmar to refuse Gregers. Because they feel that Gregers will do a bad thing to Hajlmar's life. It can be seen as the following:

Gregers. Come along out; we must have a little talk. I will go and get my coat. (Goes out.)

Gina. You oughtn't to go out with him, Hjalmar.

Relling. No, don't. Stay where you are. (Ibsen in Heffner, 1959: 398).

\section{v. Loyalty}

Ibsen's The Wild Duck teaches us the value of loyalty through the character of Hedvig. She is a source of the happiness of Ekdal's house. She is a poor child who has been convicted has nerve weakness in her eyes. That makes her unable to do as much as she wants. Although with her limitations, it does not make her just stay. She has a strong and loyal attitude. She prefers to stay at home and helps her parents as long as she can, rather than having to go to school. When Gregers talks with Hedvig about the wild duck which lives in the attic. Gregers thought Hedvig does not have time to give attention to the wild duck. Because Hedvig must spend her time for school. Hedvig said that she does not go to school because Hjalmar thought if Hedvig goes to school, it will make hurt her eyes. It can be seen as the following:

Hedvig. You couldn't help noticing it.

Gregres. Are you fond of being in there with the wild duck, too?

Hedvig. Yes, when I can-

Gregers. But I expect you haven't much time for that. I suppose you go to school?

Hedvig. No, I don't go to school any more. Father is afraid of my hurting my eyes. (Ibsen in Heffner, 1959: 387).

\section{vi. Peace-loving}

Ibsen's The Wild Duck teaches us the value of peace-loving through the character of Mr. Relling. He is a doctor. Who lives with $\mathrm{Mr}$ Molvik near with Hjalmar's studio. He is a peace-loving man, he tries to come down the hot situation between Gregers and Ekdal's family during the dinner time in Ekdal's family dining room. Mr Relling realized Gregers will bring a lot of problems to Ekdal's family. Because Gregers heard the affair between Gina (Hjalmar's wife) with his father. Mr Relling is someone who has peach loving personality. It was seen when they all gathered at Ekdal's family dining table with Gregers too. During of enjoying dinner. Mr Relling realized that the arrival of Mr Gregers would bring the problems to Hjalmar's family. Gregers always talked about things that were making every one in Hjalmar's studio be confused. Gregers speaks in using special terms such as poisonous air and that term make Gina offended. He quips Gina as a naughty woman that bring the poisonous air to the house. It can be seen as the following:

Gregers. As fas as I am concerned, I don't thrive in a poisonous atmosphere.

Relling. A poisonous atmosphere? Hjalmar. Oh, don't begin that nonsense again!

Gina. Goodness knows there's no poisonous atmosphere here, $\mathrm{Mr}$ Werle; I air the place thoroughly every mortal day. (Ibsen in Heffner, 1959: 396).

\section{b. Social Value}

Social values are principles that show how you relate meaningfully to others in social situations, including those involving family, friends, and coworkers. 


\section{i. Friendship}

Ibsen's The Wild Duck teaches us the value of friendship through the character of Gregers and Hjalmar. Since they are in primary school. They work in different fields so they are in the far distance. They never meet for more than fifteen years. They meet again in Werle's family party in their house. In this time, Werle's family is very successful in their business and Hjalmar's family is in economic problems because Old Werle has sent Old Ekdal (Hjalmar's father) to jail for his corruption as a partner with Old Werle. In such condition Gregers is still a best friend for Hjalmar, their friendship is never-ending and Gregers still invite Hjalmar for a dinner party in his house. It can be seen as the following quotation:

"Werle (with a look towards Hjalmar Ekdal). We are always accustomed to sitting down twelve. (Turns to the other guests.) Come along in here, gentlemen. (He leads the way out through the inner room and is followed by all the others except Hjalmar and Gregers.) Hjalmar (who has heard what they were saying). You shouldn't have invited me, Gregers. (Ibsen in Heffner, 1959: 356).

\section{ii. Respect}

Ibsen's The Wild Duck teaches us a value of great respect from his actors of the story. Here, Hjalmar really respects to Werle's Family because Old Werle gives him some money to build a photography studio in order to fulfil all life of Ekdal's family. Hjalmar does not know about the affair by Old Werle with his wife (Gina). He gives great respect to Old Werle because of the money. $\mathrm{He}$ comes to Gregers party and does respect to Old Werle, even though Old Werle hates his family. Hjalmar also advises his friend (Gregers) to loves his father because his father has helped him to fulfil the needs of his family. It can be seen from the following quotations:

Hjalmar. It was impossible to think of going on with my studies; we hadn't a shilling left-worse than that, there were debts, most of them owed to your father, I believe-Gregers. Hm!-Hjalmar. So that it seemed to be the best thing was to drop the old life and all its associations, once and for all. It was chiefly due to your father's advice that I did so; and as he was so kind in helping me-(Ibsen in Heffner, 1959: 358).

\section{iii. Giving back}

Ibsen's The Wild Duck teaches us the value of giving back from the actor in the story. Here, Ibsen's narrative that Hjalmar is a poor man who lives in lack of economic condition. Hjalmar is very grateful for all helps that Gregers' father (Old Werle) gives to him and his family. Even though Hjalmar and his family live in lack but Hjalmar always tries to give back for all the Old Werle's helps that he got. Through the kind heart, Hjalmar restores it. That seen when Greger leaves Werle's house, Hjalmar offers Gregers to stay in his studio even though Gina refuses his decision. It can be seen as the following quotation:

Hjalmar. Old Werle? It is no business of his.

Gina. But maybe you sure things have gone wrong between them again, as the young man is leaving his father's house. You know the sort of terms those two are on.

Hjalmar. That may be all very true, but-

Gina. And it is quite likely hs father may think that you are at the bottom of it all. (Ibsen in Heffner, 1959: 382) 


\section{iv. Contribution}

Ibsen's The Wild Duck teaches us the value of contribution through the characters in Ekdal's family. Ekdal's family is a poor family. They live in a small studio. But they don't mind to share their meal to their neighbors such as sharing some foods for lunch to Mr Relling and Mr Molvik. It makes Gina and Hedvig are very busy to prepare the food for them. They live happily with their neighbour though they are poor. Ekdal's family is a social family. They will be very pleased to give something to others. Gina is also a social person, she will be very pleased and very busy to cook for others though she will be very tired to make the best food for lunch together with her neighbour. It can be seen as the following:

(Gina and Hedvig bring in a bottle of beer, a decanter of brandy, glasses and so forth. At the same time, Relling and Molvik come in from the passage. They neither of them have hats or overcoats on; Molvik is dressed in black.)

Gina (arranging the table). Ah, you have just come at the right moment.

Relling. Molvik thought he could smell herring salad and then there was no holding him. Good morning again, Ekdal. (Ibsen in Heffner, 1959: 393).

\section{c. Personal Value}

The personal value system is basically based on two important aspects of life. One is external growth and the other is mental development. For a person external growth through material possessions, wealth, success, recognition and fame is more important than inner refinement through honesty, integrity, tolerance, sacrifice, gratitude and honesty.

i. Material possession and Wealth Ibsen's The Wild Duck teaches us the values of wealth through the character of Old Werle. He is
Gregers Werle's father, a former tradesman and business partner of Old Ekdal. He is a ruthless man, cold and interested only in financial gain. A wealthy industrialist who is responsible for the destruction of his former colleague, Old Ekdal, and his family. Werle has tried to make amends by becoming a provider of Ekdals. He also hides a liaison with Hjalmar's wife (Gina). A liaison that brings him to facilitate their marriage to avoid public scandal. On the other hand, Ekdal does not appear the tyrannical and perverse father. He is a man who would tidy up his affairs and maintain the suppression of the past at all costs. Just like Hedvig, he has eye problems that limit him from doing what he wants. It can be seen as the following quotation: Gregers (pointing to the back of the room). Look, father-Mrs.sorby is playing blind man's buff with the guests. Good-night, and goodbye. (He goes out. The Guest is heard merrily laughing as they come into another room. Werle. (muttering scornfully after Gregers). Ha! Ha! Poor chap and he says he is not sentimental!. (Ibsen in Heffner, 1959: 367).

\section{ii. Tolerance}

Ibsen's The Wild Duck teaches us the values of tolerance through the character of Gregers Werle. He is the only son of Old Werle, who feels that it is obligatory to try and undo the damage of his father. Gregers saw himself as a dog capable of rescuing an injured duck but he didn't realize that he could do more than he thought. Gregers believes that the truth will be able to help the Ekdal family to live happier lives, but he doesn't realize that the Ekdal family is happy to live a lie. It can be seen as the following quotation:

Gregers. Yes, an extraordinarily clever dog: the sort of dog that 
would go down to the bottom after wild duck, when they dive down and bite fast hold of the weed and wrack in the mud. Hjalmar. I will tell you what it is, Gregers-I doesn't understand a word of all this. (Ibsen in Heffner, 1959: 381).

\section{iii. Sacrifice}

Ibsen's The Wild Duck teaches us the values of sacrifice through the characters. Hedvig and Mrs Sorby. Hedvig is the only daughter of Gina. She is fourteen years old, she is Gina's daughter and presumably Hakon Werle's biological daughter. Gina has got pregnant after having affair with Old Werle. She is a servant of Werle and after having the pregnancy, she stops to work there and Werle also gives some money to Hjalmar to build a business. Hjalmar is very happy to receive money from Old Werle. He is very excited to build a business till has no time for Hedvig. Here, Hedvig is a tragic character, an only child who is forced to live inside her house because of her illness. She is ignored by her parents and she has no friend around her. She gets attached to the wild duck in their attic. The wild duck becomes her friend and Hedvig confines and loves the duck more than anything. However, her attachment to the duck is not as strong as her desire to prove Hjalmar that she loves him. She decides to prove to Hjalmar that she loves him by killing the duck. However, when she heard that she is not the biological daughter of Hjalmar, kills herself instead of the duck. Just like Old Ekdal, Hedvig is a wild duck, she is wounded and a prisoner of her own home. For her, the only way to be free is through her death. It can be seen as the following quotation:

Gregers. She wanted to sacrifice, for your sake, what she prized most in the world: because she believed it would make you love her again, Hjalmar. (Tenderly with emotion). Poor child! (Ibsen in Heffner, 1959: 425).

\section{d. Spiritual Value}

It refers to the importance we give to the immaterial aspects of our lives. It is part of our human need and allows us to feel fulfilled. That means the values of truth, inner peace, truth and nonviolence are found on all major spiritual paths.

\section{i. Non-violence}

Ibsen's The Wild Duck teaches the value of non-violence through the character of Hjalmar. $\mathrm{He}$ is a character who has been cheated by his wife (Gina). Did not accept about that. But Hjalmar never treats toughly to Gina. He chooses to leave his house in order to forget all about that just for a while. In that time Gregers persuades him to keep their relationships and be able to forgive everything. Hjalmar feels so disappointed by everything that has been done by Gina to him. Hjalmar feels that everything is over. Hedvig (His only daughter) is not his biological daughter and it must be a big question for him. All of Hjalmar's condition can be seen as the following:

Gregres. Indeed there is a tremendous lot here for you to think about. You three must be together if you are going to reach the goal of self-sacrificing forgiveness.

Hjalmar. I have no desire for that. Never! Never! My hat! (Takes his hat.) My home has fallen into ruins around me. (Bursts into tears.) Gregers, I have no child now! (Ibsen in Heffner, 1959: 412).

\section{e. Family Value}

Family value is the values in the family and the things that are considered good or bad. This stems from the basic 
belief of parents, who use it to educate their children.

i. Ideals

Ibsen's The Wild Duck teaches us the value of ideas through the character of Hjalmar. Hjalmar is a man who has a big motivation for his business. He has a glorious ideal. He wants through his work can carry Ekdal's family to live in better economic condition. Although his action is less than his wishes. But it shows that he has good progress to do his jobs. When Gina tells Hjalmar that she has tried to promote Hjalmar's studio, Hjalmar refuses it because he thinks Gina effort is less rigorous. It can be seen as the following:

Gina. But what am I to do? I am sure I advertise as much as I can.

Hjalmar. Yes, you advertise!-and you see how much good it does. I suppose nobody has been to look at the room, either?

Gina. Not yet.

Hjalmar. What else could you expect? If people won't keep their wits about them-. You really must pull yourself together, Gina. (Ibsen in Heffner, 1959: 374).

\section{f. Message from Hendrik Ibsen's The Wild Duck}

Ibsen's The Wild Duck is one of the best literary work that the writer has ever seen in a very long time. This drama is a tragedy. Ibsen's The Wild Duck is a form of drama based on human suffering that invites the catharsis or pleasures that accompany it.

Ibsen's The Wild Duck emphasizes many important things such as love in the family, bravery, enthusiasm to others, kind heart, peaceloving, loyalty, never giving up for improvement the morals of human's life. It also teaches us how to live in social life such as making a good friendship, respect to other, justice, honesty, giving back, and contribution for other people in the world. It teaches us to give and cares about others. The most important thing is, to be honest to others. Honesty is the basic foundation of life to reach success. Without honesty in life everything has gone be over. We can learn it from The Ibsen's The Wild Duck at the first act of the drama. It shows that there is no problem between Gregers and Old Werle in their house. But after Hjalmar knowing the tragedy in Ekdal's family, Gregers begin to unrespect to his father (Old Werle). Ekdal's family also has got the effect of the affair because Gina keeps the secret she is not honest to her husband. It makes his husband (Hjalmar) feels disappointed with her. So honesty is a basic foundation for a successful in the family.

Ibsen's The Wild Duck teaches us how to build a personal value through our material possession and wealth, tolerance and integrity for other, sacrifice. It also teaches us about spiritual value by loving and nonviolence to other, beliefs, the function of the family, and ideals in building a harmonious family's life. And we see a positive relation between Gregers and Hjalmar. They are schoolfellows but they never meet for more than fifteen years because of different jobs. They never forget their friendship. Here, we can learn that friendship is. Gives everything of his friend (Hjalmar) without receiving anything his integrity to toward Hjalmar must be followed by all the people in this world. Moreover, the character of Hedvig also sacrifices to prove that she loves Hjalmar as her father. Here, we can learn that if you love someone you have to be able to give everything for her/him.

From that story, we found many messages, one of them is honesty. That every life there is love. But love without honestly surely that will be a disaster. There is no one in the world wants to be lie. In this world, if we want to get success we really need an honestly. When we want to work or make a relation with someone. Love can change everything hatred, careless, resentment, everything can come together because of love. But love without honestly that will be a disaster. 


\section{CONCLUSION}

There are five values in analyzing a drama. Those are moral value, social value, personal value, spiritual value and family value. The values in Ibsen's The Wild Duck like learning for everybody. Moral values can be found by analyzing the treatment to others. Social values can be analyzed by a relationship in social life. Personal values can be analyzed by the character of a personal in literary work. Spiritual values can be analyzed by human needs and the last is family values can be analyzed by a relationship between others in its family. According to the analysis, it can be concluded that Ibsen's The Wild Duck teaches us the moral value by the attitude of giving of love, bravery, enthusiasm, kindhearted, loyalty, peace-loving, never giving up through his character in the drama. Ibsen's The Wild Duck teaches us the social values from the attitudes of his character in giving justice, honesty, giving back, contribution. Ibsen's The Wild Duck teaches us the personal values which are characterized by possession and wealth, integrity and sacrifice. Ibsen' The Wild Duck teaches us the spiritual values from his character through the attitudes of non-violence; Finally, Ibsen's The Wild Duck teaches us the family value by the life of the family in his character trough beliefs, function and ideal. The value of life is an overall view of self, words, human action according to the situation and also attitudes. The values of life and human life are usually influenced by input from outside himself since childhood. Norms or traditions prevailing in the community. Norms prevailing in a community are usually shared heritage, means all members of the community approves and practice. From the above Ibsen's The Wild Duck teaches us a lot of values which are useful for our life. Ibsen gives the messages through His character in the drama.

\section{REFERENCES}

Audi, R. (2007). Moral Value and Human Diversity. Oxford University Press.

Baroud, M. (2019). The Tension between Illusion and Reality in H. Ibsen's The Wild Duck. Global Journal of HUMAN-SOCIAL SCIENCE: A Arts \& Humanities - Psychology, 19(8), 23-27.

Barrows, H., Heffner, H. C., Ciardi, J., Douglas, W. W., \& Ray, G. N. (1959). An introduction to literature. Boston: Houghton Mifflin Company.
Goodman, L. (1996). Literature and Gender. London: Routledge in association with the Open University.

Gulla, A. (2010). Creating Values in Life. Bloomington: AuthorHouse.

Kenney, W. (1966). How to analyze fiction. New York: Monarch Press.

Klarer, M. (2004). An Introduction to Literary Studies. London: Routledge.

Kusumawati, K. (2017). The Underlying Motives and Manifestations of Gregers Werle's and Hjalmar Ekdal's Psyche in Henrik Ibsens' The Wild Duck. Sastra Inggris-Quill, 6(7), 740-750.

Leicester, M. (2004). Spiritual and Religious Education. London: Falmer Press.

Mathias, M. Y. (2016). Symbolic Analysis of Characters in Ibsen's The Wild Duck. Humanis: Journal of Arts and Humanities, 14(3).

Reaske, C. R. (1984). How to Analyze Drama. New York: Monarch Press.

Wellek, R., \& Warren, A. (1962). Theory of literature. New York: Harcourt, Brace \& World.

Wood, C., \& Leighton, D. (2010). Measuring Social Value The Gap between Policy and Practice. London: Demos. 